\title{
INFLUENCE OF PRESSURE GRADIENTS AND FRACTURING IN OIL FIELD ROCKS ON HYDROCARBON ACCUMULATION AND EXPLOITATION: A REVIEW
}

(Received 10, August 2008; Revision Accepted 24, July 2009)

\begin{abstract}
Earth stress at any point within a rock mass is made up of the geostatic pressure (or total stress) which is anisotropic and due to the weight of the overburden; the hydrostatic pressure which is isotropic and due to the fluid contained in the interconnected pore spaces of the rock mass; and the effective stress between the solid particles of the rock mass. Effective stress is the numerical difference between the geostatic and hydrostatic pressures. Effective stress at any point controls the value of the shear strength of the rock at that point. The higher the effective stress, the higher the shear strength and vice versa. Both the geostatic and hydrostatic pressures depend on depth below ground surface such that geostatic/hydrostatic pressure gradients exist at any point below the ground surface. Abnormal pore pressure conditions occur in rock mass when the actual hydrostatic pressure is higher than the estimated value. This condition leads to reduced effective stress and hence reduced shear strength in reservoir rocks particularly, whenever in-situ stress (or applied stress) is greater than the shear strength of the rock mass. Rock mass failure may lead to jointing and faulting. Formation of normal faults is common in deltaic over-pressured environments such as the Gulf Coast of Mexico and the Niger Delta. This has led to the formation of associated geological structures such as growth faults, roll-over anticilines and sealing faults (with shale smears), which are traps for hydrocarbon accumulation. Natural fractures formed as joint sets in shales and carbonate rocks are also good reservoirs for hydrocarbon accumulation. Fracturing at depth can also be effected artificially by creating pressure gradients by means of fluid injection. Problems associated with drilling oil and gas wells in over-pressured sedimentary basins include wellbore instability. Blowouts and lost circulation. These problems may be prevented by the use of blowout preventers and control of subsurface pressure by use of adequate mud viscosity during drilling operations.
\end{abstract}

KEY WORDS: Geostatic pressure, hydrostatic pressure, pressure gradient, overpressure, faults, reservoirs and blowouts

\section{INTRODUCTION}

Earth stress or pressure at any point within a rock mass includes the geostatic pressure and hydrostatic pressure. Geostatic pressure (total stress or lithostatic pressure) at any point within the rock mass is pressure due to weight of the overburden which depends on density of the rock mass. ( $\rho$ ), acceleration due to gravity (g) and depth ( $\mathrm{z}$ ) below ground surface. It is expressed by the following equation.

$$
\mathrm{S}=\rho \mathrm{g} z \ldots
$$

Geostatic pressure is anistropic, that is, its values at a point in a rock mass are different in deferent directions. Hydrostatic pressure (pore pressure or formation pressure) is pressure due to fluid contained in the interconnected pore spaces of the rock. It depends on density of the pore fluid $\left(\rho_{f}\right)$, acceleration due to gravity (g) and depth below the fluid surface. $\left(\mathrm{z}_{\mathrm{f}}\right)$ and is expressed as follows:

$$
P_{f}=\rho_{f} g z_{f}-\cdots
$$

Hydrostatic pressure is isotropic, that is, its values at a point in the rock mass are the same in different directions, Hydrostatic pressure may also be called formation pressure. Effective stress $(\sigma)$ at a point within the rock mass is the intergranular stress or stress due to contact between solid grains. It is obtained by subtracting the hydrostatic pressure from the geostatic pressure.

$$
\begin{aligned}
& \sigma \quad=S-P_{f} \ldots \\
& \text { Or } S=\sigma+P_{f} \ldots
\end{aligned}
$$

The geostatic pressure, hydrostatic pressure and effective stress in a rock mass act simultaneously at a point and have the same units: $\mathrm{MPa}, \mathrm{kPa}, \mathrm{kN} / \mathrm{m}^{2}$, psi etc. Since these pressures or stresses depend on the depth below the ground surface (z), and depth below ground surface $\left(z_{f}\right)$, they increase with depth below ground surface; thus geostatic/hydrostatic pressure gradients exist for the stresses (Fig.1). The units of the pressure gradients are $\mathrm{MPa} / \mathrm{m}$ or $\mathrm{psi} / \mathrm{ft}$. Pressure gradients exist at every point below the ground surface. The increased pressure at depth may cause in-situ failure or fracture of the rock mass when the shear strength of the rock mass is exceeded by the earth stress (geostatic stress, S). Tables 1 and 2 show average geostatic/hydrostatic pressure gradients of some petroleum provinces/oil fields and conditions that normally cause/facilitate failure/fracture of rock masses at depth.

O. C. Okeke, Department of Geology, Federal University of Technology Owerri, Nigeria 


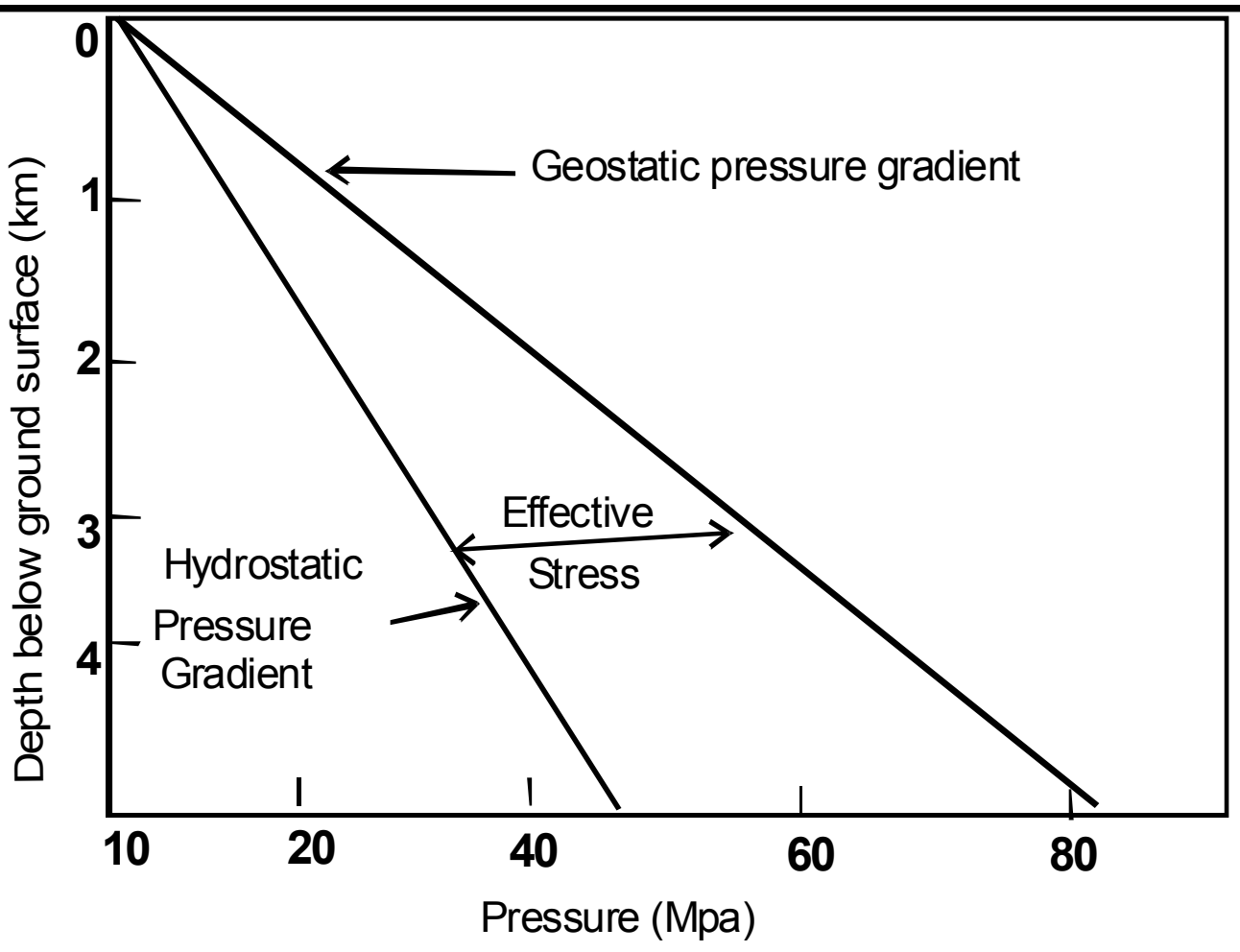

Fig. 1: Stress distribution in rocks (Schematic)

Pressure (MPa)

Table 1: Average geostatic/hydrostatic pressure gradients of some petroleum provinces/oil fields

\begin{tabular}{|c|c|c|c|}
\hline Petroleum Province/Oil Field & $\begin{array}{ll}\text { Geostatic } & \text { Pressure } \\
\text { Gradients MPa/m (psi/ft) }\end{array}$ & $\begin{array}{l}\text { Hydrostatic } \\
\text { Pressure Gradients } \\
\mathrm{MPa} / \mathrm{m} \text { (psi/ft) }\end{array}$ & Reference \\
\hline $\begin{array}{l}\text { Niger Delta } \\
\text { Gulf Coast of } \\
\text { Mexico } \\
\text { North Sea } \\
\text { Chia-Surki Oil } \\
\text { Field (Iraq) } \\
\text { Ventura Oil Field } \\
\text { (California) }\end{array}$ & $\begin{array}{l}0.023(1.00) \\
0.021(0.91) \\
0.021(0.91) \\
0.023(1.00) \\
0.023(1.00)\end{array}$ & $\begin{array}{l}0.010(0.43) \\
0.011(0.47) \\
0.010(0.43) \\
0.012(0.52) \\
0.011(0.47)\end{array}$ & $\begin{array}{l}\text { Caillet and Batiot, } \\
2003 \\
\text { Dickinson, } 1953 \\
\text { Dickinson, } 1953 \\
\text { Hubbert and } \\
\text { Rubey, } 1959 \\
\text { Levorsen, } 1985\end{array}$ \\
\hline
\end{tabular}

Table 2: Factors that may cause in-situ failure/fracture of rock mass at depths.

\begin{tabular}{|l|l|}
\hline Factors/Condition & Reference \\
\hline Effects of static loading & Hoek, 1965 \\
\hline Effects of confining pressure & Franklin and Dusseault, 1989 \\
\hline Effects of temperature & Griggs et al, 1960 \\
\hline Effects of fluid pressure & Hubbert and Rubeym 1959 \\
\hline Effects of earth movements & Anderson, 1951 \\
\hline
\end{tabular}

In this paper, the roles of pressure gradients on fracturing of rock masses and hydrocarbon migration/accumulation in porous and fractured rocks, particularly oil field rocks, are reviewed; some drilling problems associated with pressure gradients are also highlighted. 


\section{OCCURRENCE OF ABNORMAL PRESSURES IN ROCK MASSES}

Abnormal pore pressures occur in rock masses when fluid in a compacting low-permeability argillaceous rocks such as clay and shales (with coefficients of permeability of less than $1 \times 10^{-7} \mathrm{~m} / \mathrm{s}$ ) cannot easily be expelled to the surface or nearby high permeability rocks such as sandstone (coefficient of permeability greater than $1 \times 10^{-2} \mathrm{~m} / \mathrm{s}$ ). In such low permeability rocks (clay and shale) the rate of expulsion or pore fluid is not able to keep pace with the rate of compaction, thus pore pressure increases above the normal for the depth of burial. Magara (1975) described the phenomenon as disequilibrium compaction and the shale/clay undergoing compaction is said to be undercompacted. Such shales or clays are said to be over-pressured or geopressured (Stuart, 1970). Any sand body either interbedded in, or contiguous with the shale will also be overpressured if it is isolated from the surface either by pinch-out (stratigraphic trap) or faulting (structural trap). Geopressures or overpressures can therefore occur in both sands and shales, even though it may have originated in the shales. Overpressures may have values that are up to geostatic pressure, and the higher the values, the less the effective stress (since $\sigma=S-$
$P_{f}$ ), and consequently the less the shear strength of the over-pressured rock. Occurrence of overpressures in rocks can therefore reduce the strength of the rock mass. Figure 2 shows geological structures that are normally overpressured while Figure 3 shows a model of overpressures across growth faults in the Niger Delta.

Overpressures generally occur at great depths [3047.8m (10000ft)] when the weight of overburden is high enough to initiate disequilibrium compaction. They may also occur at quite shallow depths [below 1521.4m (500ft)] as in the Forties Oil Field, North Sea, where overpressure was encountered at depth of $1217.5 \mathrm{~m}$ (4000ft). Shallow overpressures may occur as a result of bed movements or displacements associated with formation of growth faults and rollover anticlines in a deltaic environment. Shallow overpressures are however rare.

Petrophysical properties of rocks such as temperature and bulk density that vary with depth of burial also have direct relationship with pressure gradient. These properties (temperature and bulk density) normally influence the values of pressure at great depth and are may therefore be used in the prediction of pressures at great depths (Fertl, 1977, Levorsen, 1985).

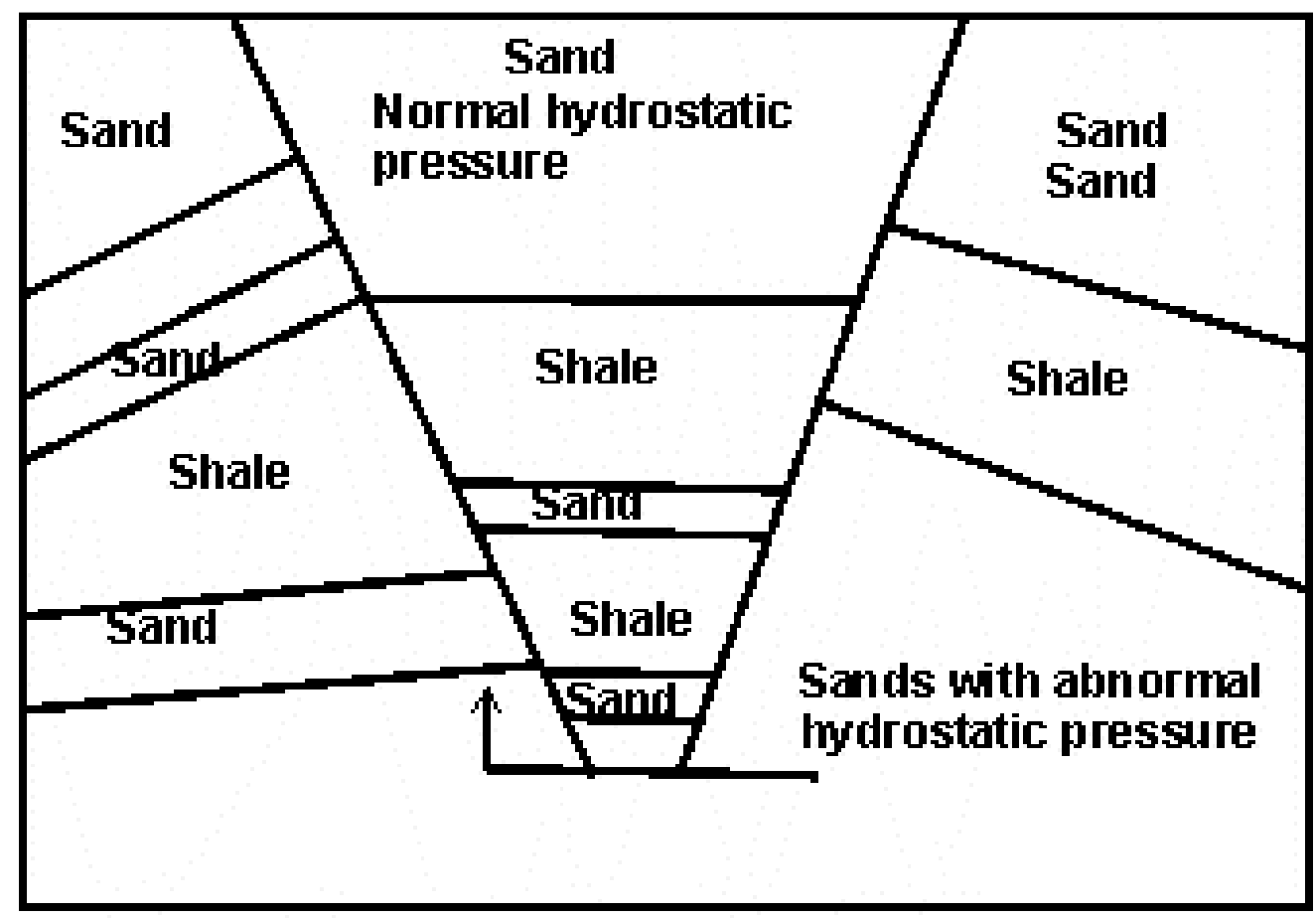

Fig. 2 Reservoir seal with abnormal pressures (Dickinson, 1953) 


\section{Pressure (Mipa)}

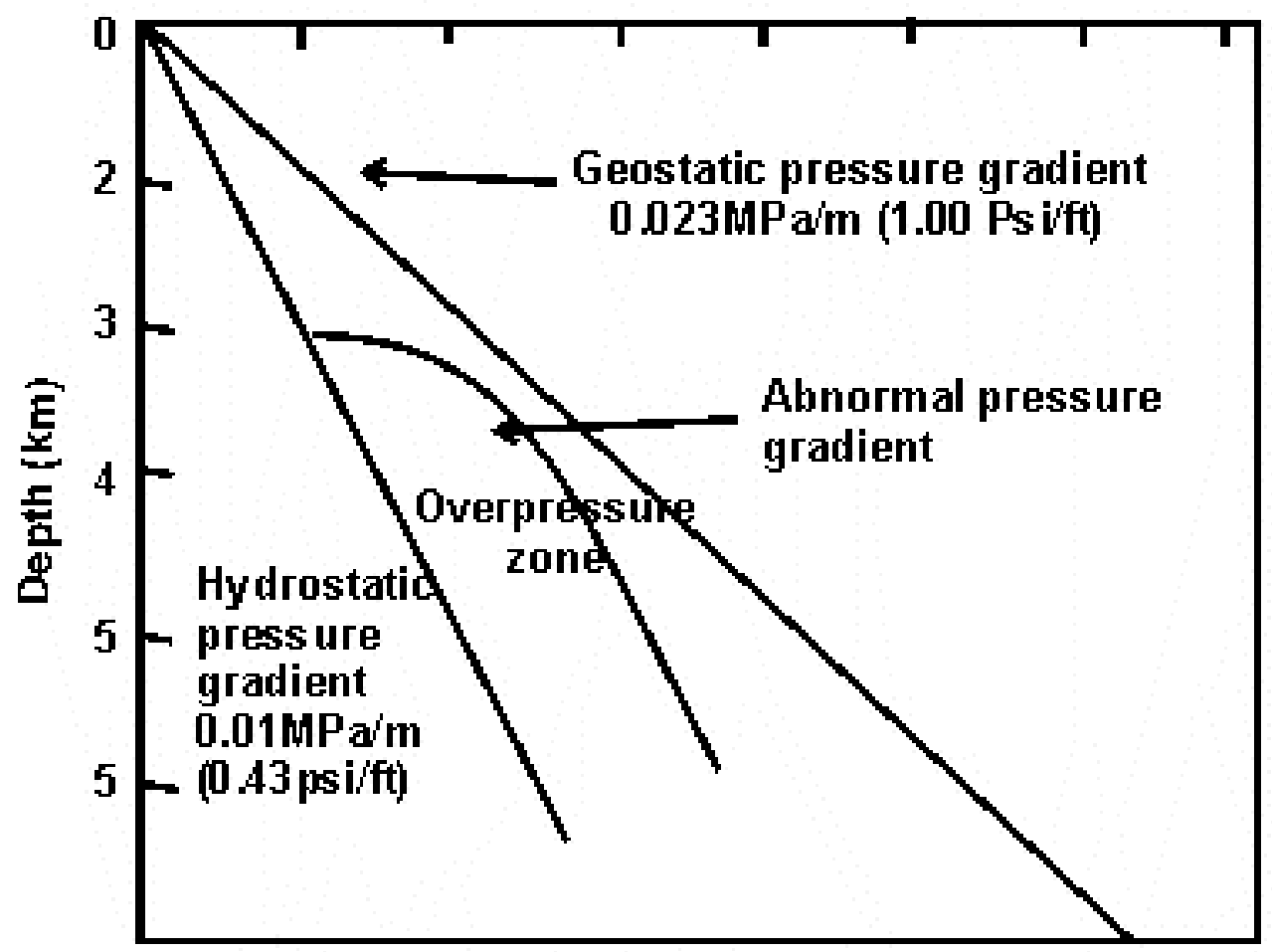

Fig. 3: Occurrence of overpressures in the Niger Delta (Caillet and Batiot, 2003)

\section{INFLUENCE OF PRESSURE GRADIENTS AND FRACTURING IN OIL FIELD ROCKS ON HYDROCARBON ACCUMULATION AND EXPLOITATION}

The influence of pressure gradients in oil field rocks on hydrocarbon accumulation and exploitation cover the role of pressure gradients in hydrocarbon migration and production, and drilling problems of welbore instability, blowouts and lost circulation. The influence of fracturing in oil field rocks on hydrocarbon accumulation and exploitation include role played by faults as hydrocarbon migration/leakage pathways, and as seals or barriers in hydrocarbon traps. Naturally fractured rocks may also be useful as hydrocarbon reservoirs, while artificial fracturing of rocks by fluid injection at depth may be used to enhance secondary recovery of hydrocarbon. These are discussed below.

\section{Role of Pressure Gradient in Hydrocarbon Migration and production}

Hydrocarbon, once formed in the pores of shale source rocks undergo two stages of migration before they may be accumulated in the traps. These are the primary migration which is the expulsion or squeezing of petroleum out of the source rocks into the nearby porous rock; and the secondary migration which is the movement of the petroleum oil/gas in the porous rocks to the reservoirs/traps (Levorsen, 1985). Many theories, including diastrophic theory and sedimentary compaction theory, have been used to explain the expulsion of petroleum from source rocks. Basically these theories involve the expulsion of water containing dissolved/dispersed gas/oil at higher pressure from the pores of the shale source rocks due to increased pressure at depth. The oil/gas is released from the solution as the pressure drops.

The secondary migration of hydrocarbon in the reservoir rocks to the traps and from the traps to oil/gas wells is controlled by the difference in fluid potential between the two locations. Fluids normally move from the zone of higher potential to the zone of lower potential. In effect, the movement may be vertical or horizontal depending on the pathways available (porous media, bedding planes, faults, etc.). According to Hubbert (1953), the relationship between fluid pressure (formation pressure) and fluid potential is given as:

$$
\begin{aligned}
& =g z+P / \rho . \\
& \text { where } \square=\text { fluid potential } \\
& \mathrm{g}=\text { gravitational constant } \\
& z=\text { elevation at the site of pressure }
\end{aligned}
$$

measurement in relation to a known datum

$\mathrm{P}=$ static fluid pressure (hydrostatic)

$\rho=$ density of reference fluid (usually

water)

The fluid potential is related to the "head" or potentiometric surface $(h)$ by the following relationship

$$
\square=\mathrm{gh}
$$

And dividing both relationships by $\mathrm{g}$, the following equation is obtained 


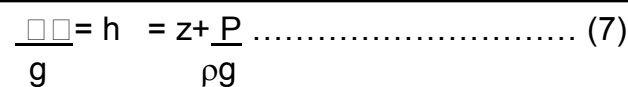

It is this relationship that is commonly employed to convert fluid pressure (formation pressure) to fluid potential values as represented by $h$, the potentiometric head.

During hydrocarbon production, the fluid potential $(\mathrm{h})$ naturally declines but this can be improved by injection of fluid into the reservoir to maintain the fluid potential (or fluid pressure) necessary to drive the hydrocarbon to the surface. According to Offshore Engineer (2005) and Petroconsultants (1996), about $100 \mathrm{bcf}$ of Nigeria's annual natural gas production of $1 \mathrm{tcf}$ (i.e 10\%) is reinjected into the reservoirs to maintain reservoir pressure necessary for continuous crude oil production.

\section{Drilling Problem of Wellbore Instability}

Wellbore instability is crumbling (break-out) or caving of the walls of the wellbore during drilling operations. According to Cheatam (1984), it may occur as a result of strength reduction associated with pressure gradients between the wellbore and the oil field rocks (horizontal stress) or strength reduction associated with hydration of near-wellbore rocks (in the case of shale formations) by drilling fluids.

Wellbore instability often leads to well enlargement when fragments of brittle rocks such as sandstone fall off the wall of the well or well tightening when wellbore formation rock such as shale is squeezed into the wellbore.

In deep wells, rock strength failure near the wellbore may also be caused by repeated variations in the hydrostatic pressure during around trips and temperature variations.

When different pressures are created in the wellbore and formation fluids flow between the two media (drilling fluid flowing into the formation or fluid flowing into a well), hydraulic pressure gradient is established between the two media. The pressure gradient may lead to brittle failure of consolidated reservoir rocks (example, sandstone) or plastic deformation of soft rocks (example, shale).

When drilling fluid is used to prevent the collapse of the well-bore, hydraulic pressure gradient established is given as:

$$
\Delta P=P_{m}-P_{f}
$$

where $\Delta P=$ hydraulic pressure gradient pressure)

$P_{m}=$ pressure from the drilling fluid (mud

$P_{f}=$ pore pressure or formation pressure.

Wellbore instability caused by hydraulic pressure gradient may be controlled by controlling drilling mud pressure so that $P_{m}-P_{f}$ is as small as possible.

Wellbore instability caused by hydration of shale formation by drilling fluid occurs due to swelling of expansive clays contained in the shales which leads to reduction in the hole-size. Use of potassium - based drilling fluid will also prevent the hydration of the shales and wellbore tightening (reduction of well size).

\section{Drilling Problem of Blowouts.}

Blowouts can occur when abnormal formation pressures are encountered during drilling such that the pressure of the drilling fluid cannot balance the excess overpressures or geo-pressures. In such situations gas and other formation fluids flow suddenly into the oil/gas well and to the surface if not controlled. Signs of imminent blowouts are gas/oil showings on the mud and increase in flow, sometimes violently. Blowouts may cause fire, loss of drilling equipment and sometimes loss of human life.

Occurrence of blowouts is common in all overpressured oil provinces including the Niger Delta, the North Sea and the Gulf Coast of Mexico (Dickinson, 1953; Fertl, 1976; Obah, 1989). Effective control of overpressures depends on prediction of its occurrence. Approaches normally used in its prediction include the use of well-logs (Hottman and Johnson, 1965; Zoeller, 1984) and surface measurements of density of drill cuttings (Fertl, 1977).

In order to prevent the occurrence of blowouts, the underlisted precautions should be applied:

(a) the well head should be fitted with blowout preventers. This should be shut immediately there is evidence that blowout is about to occur;

(b) the density of drilling fluid in the well should be increased regularly to a level that is high enough to maintain slight excess pressure in the well over the formation pressure but below the value that may cause induced fracturing; and

(c) the drilling fluid should be regularly degassed. If there is considerable increase in the gas content, drilling should be suspended and the drilling fluid replaced with fresh one.

\section{Drilling Problem of Lost Circulation}

Lost circulation occurs during drilling when fluid flows continuously from the well into the formation, thus reducing the volume of fluid in circulation. Lost circulation may occur when:

(a) the rock has open fractures or channels and pressures exerted by the drilling fluid (or mud) on the borehole walls exceeds the formation pressure in a given horizon; and

(b) the pressure exerted by the drilling fluid (or mud) on the borehole wall is high enough to open up close micro fractures or cause formation of new fractures (induced fracturing). According to Sereda and Solovyov (1977), the adverse consequences of lost circulation include:

increase in the quantity of drilling fluid needed to sink a well,

increase in working time used by drillers to prepare the drilling fluid mixture that will stop lost circulation and overall increase in the cost of drilling the well; and

(b) lost circulation generally leads to reduced level of mud in the, followed by inflow of brine water/gas from the formation (blowout) due to back pressure on the borehole walls.

Lost circulation may be controlled by prevention of the development or occurrence of any of the causative factors. The pressure from the drilling fluid must be higher than the formation pressure to prevent inflow of formation fluid into the well but not very high as to cause induced fracturing of the formation rocks. The equations 
below satisfy the two conditions (Serada and Solovyov, 1977):

\begin{tabular}{|c|c|c|c|}
\hline \multirow{3}{*}{$P_{b} Z$} & $P_{m}$ & $>$ & $\begin{array}{l}{[v /(1-v)]\left(S-P_{f}\right)+P_{f}} \\
. . .(9)\end{array}$ \\
\hline & $\begin{array}{r}\mathrm{P}_{\mathrm{m}} \\
\ldots \ldots\end{array}$ & $\begin{array}{l}+ \\
\ldots(10)\end{array}$ & {$[v /(1-v)]\left(S-p_{f}\right)+P_{f}<$} \\
\hline & where $P_{m}$ & 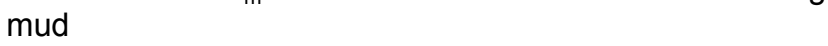 & Pressure from drilling \\
\hline & v & $=$ & Poisson's ratio \\
\hline & $\mathrm{S}$ & $=$ & stress \\
\hline \multicolumn{4}{|c|}{ Geostatic pressure } \\
\hline hydros & $\begin{array}{l}\quad \mathrm{P}_{\mathrm{f}} \\
\text { atic pressure }\end{array}$ & $=$ & Formation pressure or \\
\hline & $\begin{array}{l}P_{b} \\
Z\end{array}$ & $\begin{array}{l}= \\
=\end{array}$ & $\begin{array}{l}\text { Fracture gradient } \\
\text { Depth of the horizon }\end{array}$ \\
\hline
\end{tabular}

Fracture gradients of most rocks range from 0.012 to $0.026 \mathrm{MPa} / \mathrm{m}$ (0.522 - 1.130 psi/ft (Eaton, 1969; Sereda and Solovyov, 1977). Formation pressure may be determined from resistivity logs using MWD technique.

\section{Role of Faults as Hydrocarbon Migration/Leakage Pathways}

Faults are fractures in the earth in which noticeable displacements have taken place. As already stated, they can originate from over-pressured conditions in rock masses when shear strengths resulting from overpressures are overcome by in-situ or applied stresses. Apart from being the possible pathways through which hydrocarbon can move from one reservoir to another if fluid potential exist between them, faults are also good migration pathways from source rock to reservoirs. The distance of migration may be long as in the Gulf of Mexico for movement of oil from Jurassic shale source rock to the Miocene sand reservoir rocks (Antoine, 1972). The distance may be short as in the case of Niger Delta where the hydrocarbon moves from the shale source rock of Akata/Agbada Formations to the sandstones of Agbada Formation through the intricate system of faults in the area (Evamy et al, 1978). In these two instances(that is the Gulf of Mexico and the Niger Delta), movement is usually along faults. Occasionally, movement may be across faults if there is breakage of shale smear along faults as is the case in the Niger Delta (with some diapirism in the Akafa Formation). Hydrocarbon migration along faults may leak to the surface or leak into porous media where it may not be trapped to form a pool. In such a circumstance, oil sands (tar sands) may be formed as in the case of Southwestern parts of Nigeria, Canada and Azerbaijan (Caspian Sea). Oil production from Canadian tar sands is currently $140,000 \mathrm{~b} / \mathrm{d}$ (The Leading Edge, 2005). The tar sands deposit in Southwestern Nigeria has been estimated to be over 30 billion barrels of oil equivalent (Nwachukwu, 2003).
6. Role of Faults as Seals in Structural Traps

The trapping potential of faults depends on their ability to act as impermeable seals or barrier to flow of fluid. Fig 4 shows typical fault related structural traps with oil pools. Most faults associated with structural traps either as normal or reverse faults, or faults of salt tectonism and diapirism act as impermeable barriers flow of fluid (sealing fault) thus trapping the petroleum. Faults as impermeable barriers can also impede the recovery of hydrocarbon during production. According to Bretan et al (2004), a fault developed in mixed clastic sediments can be sealing to hydrocarbon sediments in two ways:

a) if fault movement has resulted in the juxtaposition of non-reservoir intervals (shale) and reservoir intervals (sand); and

b) if fault movement has resulted in the development of shale smear or shale gouge in the fault zone arising from fault related deformation process.

The term shale smearing encompasses shearing-based mechanisms responsible for incorporating shale into fault zones (Aydin and Eyal, 2002). Sealing faults have been reported in major petroleum provinces of the world including the Niger Delta (Bouvier et al, 1989; Koledoye et al, 2003), Gulf Coast of Mexico (Perkins, 1961) and the North Sea (Knott, 1993; Fristard et al, 1997).

In rapidly sedimenting basins such as the Niger Delta, the Gulf Coast of Mexico and the North Sea, growth faults are always formed. These are normal faults that are sub-vertical near the surface but increase in dip downwards until apparently they become coincident with the bedding plane shear surfaces deep down in the prodelta (Ocamb, 1961; Xio and Suppe, 1992). The sand/shale ratio (stratigraphic units) increases with depth, and the amount of throw of the faults also increases with depth.

Oil and gas may be trapped due to the growth faults in two ways. The trap may be a classic fault trap when the sand abuts against the fault. Alternatively, oil may be trapped in a roll-over anticline where the beds turn over to dip into the plane of the fault. Fig 5 shows growth faults from the Niger Delta (Weber et al, 1978). Fault traps may also be formed by salt domes (salt tectonism) as in the Gulf of Mexico (Smith, 1980). 


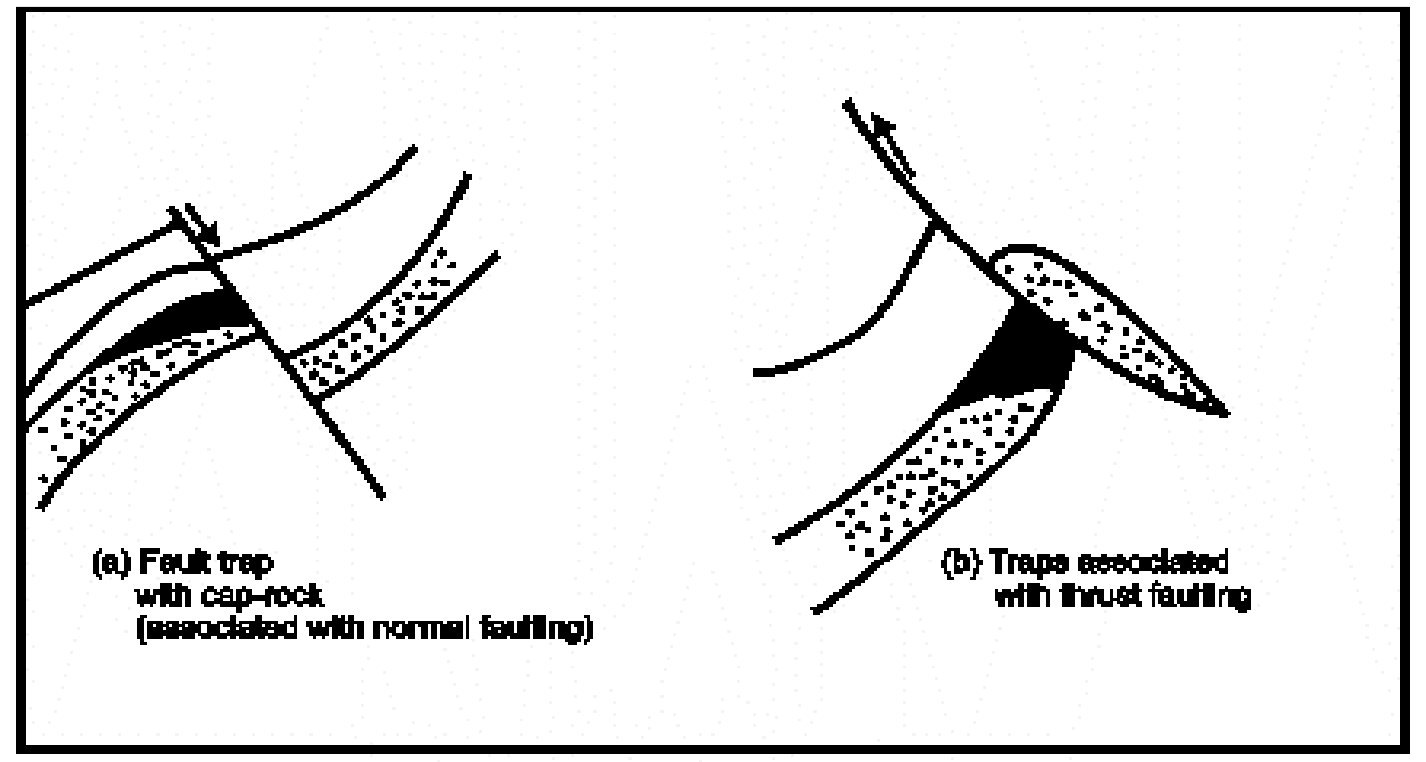

Fig. 4: F ault - related structur al traps with oil pools (Adapted from Levorsen, 1985)

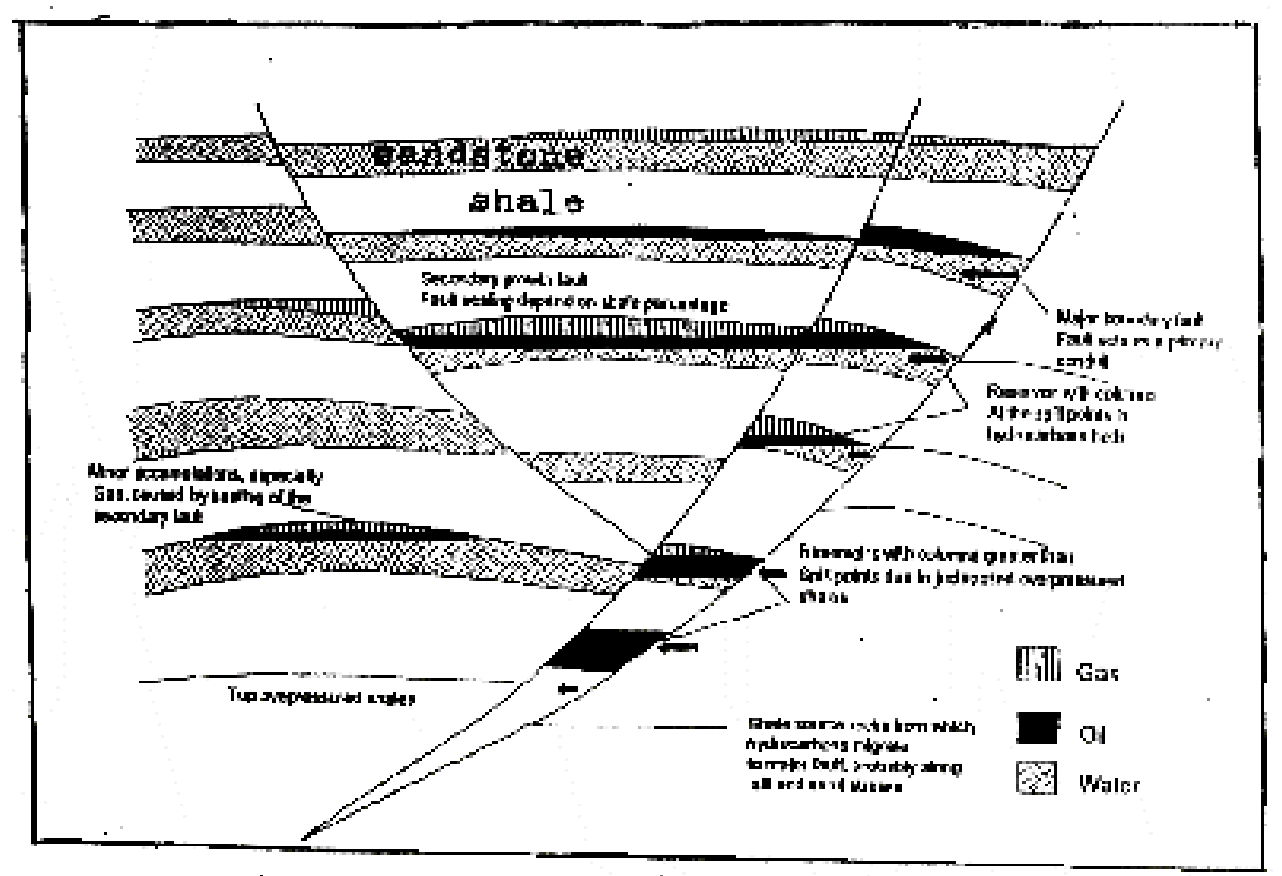

Fig. 5: Growth faults from the Niger Delta (Weber et al, 1978) 


\section{7.}

Role of Naturally Fractured Rocks as Oil/Gas
Reservoirs

\section{Reservoirs}

Rocks such as limestone, granite and shale are generally impermeable and therefore may not serve as hydrocarbon reservoirs. When naturally fractured at depth however, they are good hydrocarbon reservoirs. When fractured their porosities and permeabilities are increased and the pores become interconnected. Nearly all limestone and dolomite reservoirs worldwide are fractured rocks. Igneous and metamorphic rocks are occasionally fractured to provide oil/gas reservoirs. (Levorsen 1985)

Some examples of naturally fractured reservoirs are given below:

(a) Fractured limestone reservoir of West Edmond Oil Field in Oklahoma, USA (Hubbert and Willis, 1955);

(b) Fractured shale-oil reservoir of Spraberry Oil Field, Western Texas (Hubbert and Willis, 1955);

(c) Fractured shale gas reservoirs in USA (USGS, 1995; Curtis, 2002).

(d) Fractured granite basement rock of Vietnam (Explorer, 2005).

8. Artificial Fracturing of Rocks at Depth to Improve Reservoir Productivity.

The porosity and permeability of most oil/gas producing wells in both sandstone and other fractured rocks including limestones and shales decrease with time due to influx of sands (sand production) into the pores and borehole or closure of the pores as the fluid is withdrawn in the case of fractures. Hydraulic fracturing is a technique of artificially fracturing rocks at depth by injection of fluid under high pressure into a sealed-off section of unfractured borehole (Martinez et al, 1992). Roegiers (1993) defined it as a special type of induced instability whereby a section of the borehole is pressurized until failure occurs. According to Veatch and Moschovidis (1993), about $35 \%$ to $40 \%$ of all oil/gas wells currently drilled in the petroleum industry worldwide are hydraulically fractured. Hydraulic fracturing is responsible for increasing North America's oil reserves by more than 8 billion bbl $\left(1.3 \times 10^{9} \mathrm{~m}^{3}\right)$ (Girdley et al, 1989). Hydraulic fracturing can be used successfully in all rocks except the very soft ones. Sandstone, limestone, dolomites, conglomerates and hard/brittle shales have been successfully fractured. The plastic nature of shales and clays makes them difficult to fracture. There is no lower or upper depth limits in the effectiveness of hydraulic fracturing but records exist for improvement of permeabilities for values less than 0.1 $\mathrm{md}$ to as high as $910 \mathrm{md}$.

\section{CONCLUSIONS}

Pressure gradients in rock masses particularly in reservoir rocks are responsible for fracturing of rock masses to form joints and faults. Temperature gradients and tectonic forces (earth movements) in rock masses may also contribute (in association with pressure gradients) to reservoir rock fracturing. The expulsion of hydrocarbon from source rocks and its movement or migration to the reservoirs/traps, oil wells and to the surface are due to pressure gradients. The drilling problems of well bore instability, blowouts and lost circulation are related to geostatic/hydrostatic pressure gradients in oil field rocks and may be controlled by adequate monitoring/adjustment of drilling fluid density during drilling operations.

The faults may serve as migration/leakage pathways or structural traps for hydrocarbons. Growth faults are normal faults formed as a result of rapid sedimentation process in overpressured deltaic environments (rapidly subsiding basins). Overpressures or abnormal hydrostatic pressures in rock masses occur when the saturated low permeability rocks such as clays and shales cannot easily release fluids contained in them when they are compacted during sedimentation; with the fluids remaining in the pore spaces as overpressures. The overpressures once formed in clays or shales may spread to other nearby rocks. Overpressures are responsible for the drilling problem of blowouts. Naturally fractured shales and carbonate rocks are also hydrocarbon reservoirs. Hydraulic fracturing of the oil field rocks at depth by fluid injection is usually applied to improve reservoir characteristics of porosity and permeability thereby enhancing production of oil/gas.

\section{REFERENCES}

Anderson, E. M., 1951. The Dynamics of Faulting. Oliver and Boyd Ltd, Edinburgh. 251p.

Antoine, J. W., 1972. Structure of the Gulf of Mexico. In: Contributions on Geological and Geophysical Oceanography of the Gulf of Mexico; Texas A\&M University Oceanographic Studies, Vol. 3 (R, Razeke and V. J. Henry, Eds.), Gulf Publishing Company Houston, pp. $301-324$.

Aydin, A. and Eyal, Y., 2002. Anatomy of a Normal Fault with Shale Smear: Implications for Fault Seal. AAPG Bull. 86, (8): pp. 1367 - 1381.

Bouvier, J. O., Kaars Slipasteigein, C. H., Kluesner, D.F., Onyejekwe, C.C. and Van Der Pal, R. C., 1989. Three Dimensional Seismic Interpretation and Fault Sealing Investigations, Nun River Field, Nigeria. AAPG Bull. 73: pp. 1397 - 1414.

Bretan, P. Freeman, B., Jones, S., Yielding, G., Koledoye, B., Yussuph, W. and Mokwe, C., 2004. Method for Fault-Seal Prediction: A worked example from the Niger Delta. NAPE Bull., 17 (1): pp. $48-60$.

Caillet, G. and Batiot, C., 2003. 2D Modelling of Hydrocarbon Migration Along and Across Growth Faults. An Example from Nigeria. Petroleum Geoscience, 9: pp. 113 - 124.

Cheatam, J. B., 1984. Wellbore Stability. J. Pet Tech. (June 1984), pp. 859 -869.

Curtis, J. B., 2002. Fractured Shale Gas Systems. AAPG Bull. 86, (11): pp 1923 - 1938.

Dickinson, 1953. Geological Aspects of Abnormal Pressures in the Gulf Coast of Louisiana. AAPG Bull. 37, (2): pp 410 - 432. 
Eaton, B. A., 1969. Fracture Gradient Prediction and its Application in Oil Field Operations. J. Pet. Tech. (Oct., 1969), pp. 1353 - 1360.

Evamy, B. D., Haremboure, J., Kennedy, P., Knaap, W.A., Melly, F. A. and Rowland R. H., 1978. Hydrocarbon Habitat of Tertiary Niger Delta. AAPG Bull. 62: pp. 277 - 298.

Explorer, 2005. Vietnam Finds Oil in the Basement. AAPG Explorer, 26, (2): pp. 8 - 10.

Fertl, W. H. (Ed.), 1976. Abnormal Formation Pressures - Implications to Exploration, Drilling and Production of Oil and Gas Resources. Elsevier, Amsterdam.

Fertl, W. H., 1977. Shale Density Studies and their Applications. In: Developments in Petroleum Geology 1(G.D. Hobson, Ed.) Applied Science Publishers Limited London, pp. 293 - 327.

Franklin, J. A. and Dusseault, M. B., 1989. Rock Engineering. McGraw - Hill Publishing Company, New York.

Fristard, T. Groth, A., Yielding, G. and Freeman, B. 1997. Quantitative Fault Seal Prediction: A Case Study from Oseberg Syd. In: Hydrocarbon Seals, Importance for Exploration and Production ( $P$. Moller - Pedersen and A. G. Koestler, Eds.) NPF Special Publication No. 7, Elsevier, Singapore, pp. 107 - 124.

Girdley J. C. Holditch, S. A., Nerode, D. E and Veatch, R. W. 1989. Recent Advances in Hydraulic Fracturing. Monograph Series, SPE. 12:, Richardson, Texas.

Griggs, D. T., Turner, F. J. and Heard, N. C., 1960. Deformation of Rocks at $500^{\circ} \mathrm{F}$ to $800^{\circ} \mathrm{F}$. GSA Memoir (79): pp. 39 - 104.

Hoek, E., 1965. Rock Fracture Under Static Stress Conditions. National Mechanical Eng. Res. Institute, Pretoria. CSIR Report MEG 383, pp. 70-75.

Hottman, C. E. and Johnson, R. K., 1965. Estimation of Porepressure from Log-Derived Shale Properties. J. Pet. Tech. (June 1965), Trans. AIME, 234, pp. 717 - 722.

Hubbert, M. K., 1953. Entrapment of Petroleum Under Hydrodynamic Conditions. AAPG Bull. 37 (August, 1953), pp. 1954 - 2026.

Hubbert, M. K. and Rubey, W.W 1959. Role of Fluid Pressure in Mechanics of Overthrust Faulting, GSA Bull. 70, pp. 115 - 166.

Hubbert, M. K. and Willis, D.G., 1955. Important Fractured Reservoirs in the United States. Proc. World Petroleum Congress, (June 1955) Texas, pp. $57-84$.
Knott, S. D., 1993. Fault Seal Analysis in the North Sea. AAPG Bull. 77, pp. 778 - 792.

Koledoye, A., Aydin A, and May, E., 2003. A New Process - Based Methodology for Analysis of Shale Smear Along Normal Faults in the Niger Delta. AAPG Bull. 87, pp. 445 - 464.

Levorsen, A. I., 1985. Geology of Petroleum, $2^{\text {nd }}$ Edition $\left(1^{\text {st }}\right.$ Indian Edition), CBS Publishers \& Distributors. New Delhi, India, 560p.

Magara, K., 1975. Re-evaluation of Montmorillonite-llite Dehydration as a Cause of Abnormal Pressure and Hydrocarbon Migration. AAPG Bull. 64, pp. $708-721$.

Martinez, S. J., Steancon, R. E and Couler, A. W., 1992. Formation Fracturing, In: Petroleum Engineering Handbook (H.B Bradley, Ed.) SPE, Richardson TX pp. 55.1 - 55.12.

Nwachukwu, J. O. 2003. The Bitumen Deposits of Nigeria. NAPE News, 3, (2): p. 11.

Obah, B. 1989, Over-pressures - A Drilling Hazard in the Niger Delta, Erdol Und Koble, Erdgas Petrolechemie, Vol. 42, (9): pp. 340 - 343.

Ocamb, R. D., 1961. Growth Faults of South Louisiana. Trans. Gulf Coast Association of Geological Societies, 11 pp. 139 - 176.

Offshore Engineer, 2005. Converting Gas to Cash. Atlantic Communications, Houston, Texas (March, 2005) pp. 61 - 62.

Perkins, H. 1961. Fault Closure - Type Fields, Southern Louisana. Trans, Gulf Coast Association of Geological Societies. 11, pp. 203 - 212.

Petroconsultants, 1996. Petroleum Exploration and Production Data Base, Houston, Texas. Petroconsultants Inc. P. O. Box 740619, Houston, Texas, 94p.

Roegiers J. C., 1993. The Use of Rock Mechanics in Petroleum Engineering - General Overview. In: Comprehensive Rock Engineering (J.A. Hudson, Ed.) Pergamon Press, Oxford, 5, pp. $603-616$.

Sereda, N. G. and Solovyov, E. M., 1977. Drilling of Oil and Gas Wells, Mir Publishers, Moscow, 571p.

Smith, D. A., 1980. Sealing and Non-Sealing Faults in Louisiana Gulf Coast Salt Basin. AAPG Bull. 64, pp. $145-172$.

Staurt, C. A., 1970. Geopressures. Supplement to Proc., $2^{\text {nd }}$ Symposium on Abnormal Sub-Surface Pressure. Louisiana State University, Batin Range, LA, 210p.

The Leading Edge, 2005. Review of HIS Energy Report on 10 - Year Petroleum Trends (1994 - 2003). SEG, Tulsa, 24, (1) pp. 28 - 31. 
USGS, 1995. National Assessment of United States Oil and Gas Resources. United States Geological Survey, U. S. Government Printing Office, Washington D. C., 700p.

Veatch, R. W. and Moschovidis, Z. A., 1993. Hydraulic Fracturing - The Significance of In-situ Stresses and Rock Mechanics. In: Comprehensive Rock Engineering (J. A. Hudson, Ed.). Pergamon Press, Oxford, 5, pp. 617 - 628.

Weber, K. J., Mandl, G., Pilaar, W. F., Lehner, F. and Precious, R. G., 1978. The Role of Faults in Hydrocarbon Migration and Trapping in Nigerian Growth Fault Structures. Proc. American Institute of Mining, Metallurgical and Petroleum Engineers and SPE $10^{\text {th }}$ Annual Tech. Conference, 4, pp. 2643 - 2653.

Xiao, H. and Suppe J., 1992. Origin of Rollover. AAPG Bull. 76: pp. 505 - 529.

Zoeller, W. A., 1984, Determine Pore Pressure from MWD Logs. World Oil (March, 1984), pp. 97 102. 